\title{
Fragile Selves: Constructing Identity in Novels by Margaret Clark, Nette Hilton and Isobel Carmody
}

\author{
Richard Rossiter
}

\begin{abstract}
Australian children's literature, in its production and dissemination, is heavily committed to particularvalues and processes: it seeks to promote maturation, liberation and transcendence as shaped by a humanistic vision of moral commitment and altruism

(Stephens 1996, p.163)
\end{abstract}

I n this statement John Stephens identifies not only a dominant liberal humanist tradition within Australian children's literature. but also its conventions: a commitment to a realist mode of writing. The logical extension of this position is underlined by Stephens further observation that 'Australian children's literature itself remains virtually untouched by postmodernism (Stephens 1996, p. 162).

The nature of a 'humanistic vision' is encapsulated in Catherine Belsey's statement that

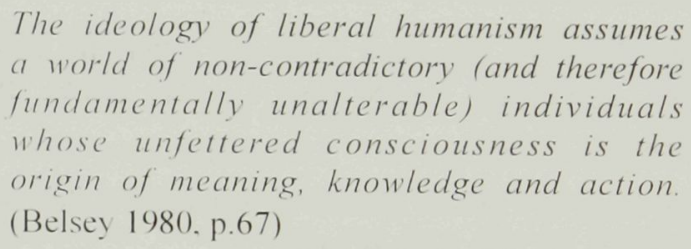

It is the mode of realism that is concerned with representing subjects who are 'the origin of meaning, knowledge and action' and who are 'fundamentally unalterable'. By contrast, the postmodern view of the subject, with its indebtedness to poststructuralism, argues that subjectivity 'is constructed in language and discourse; and rather than being fixed and unified, the subject is split, unstable or fragmented. ' (Rice and Waugh 1996, p.123). It is this subject that Stephens argues is virtually absent from Australian children's literature

Within this framework of competing ideologies and competing notions of the subject, I wish to examine three contemporary Australian novels: Margaret Clark's Back on Track: Diary of a Street Kid (1995), Nette Hilton's Hothouse Flowers (1997) and Isobel Carmody's Greylands (1997). My particular interest is in how these novels establish notions of the subject and the tensions that exist between their postmodern elements and a realist tradition. I wish to argue that there are moments in these texts where they begin to interrogate, consciously or unconsciously, their own predominant generic conventions, and thus the status of their subjects.

ThroughoutNette Hilton's Hothouse Flowers there appears to be a rejection of the liberal humanist notion of a unified subject, the self as origin of meaning and action. At one point the male protagonist. Axel, reflects on the fact that he didn't exist for his aunt, his mother, or the blokes that used to follow her home:

The only person he existed for was her, Gran, and she only remembered him on some days now. Already he was fading into oblivion before the string had time to run out. (Hilton 1997, p.82)

From the beginning of the novel Axel is convinced that the end of the string — the end of his life — is not far off. In the passage just quoted it would seem that, for Axel, the disappearance of the self is linked to a failure to be recognised; in other words he does not exist as an autonomous, independent being. And because there is no network or structure - personal. social. or ideological - to bring him into existence, or to use Althusser's term (1977, in Rice \& Waugh 1989, p.58), to interpellate him as a subject, then he scarcely exists at all.

The character who begins to fulfil this role of recognition for Axel is the manic-depressive, Rose, who happens upon him. When she begins her jungle mural, Axel is impressed, but says that it would be nice to have a zebra in the picture. This poses a problem for the multi-coloured Rose (who, incidentally, is defined by her illness) because, significantly she does not have any black, or white, paint. However, she gets the necessary colours and produces the zebra. But to do so she paints out the rest of the jungle:

Leaves and bugs, lions and giraffes were being covered... She wept while she did it, wept as each colour and shape disappeared under her misery. She cried for them and cried for the loss of what she ached to be. (p. 149) 
So the zebra comes to represent a reduced sense of self for Rose, and it becomes the gift that 'recognises' Axel. We are told,

in the gift of a zebra she had painted him. She had placed him in the centre of life and movement. She had given him beauty in its simplest form with no colour to liven it. (p. 174)

At the moment when Axel is once again on the edge of the cliff, contemplating suicide, the zebra which now seems to exist in some space apart from the painting, watches over him and prevents Axel's final inaction, his failure to jump over.

The central motif of the painting suggests a number of meanings. As 'Nature' it could be seen as counterbalancing the dominance of the technological in contemporary society. In other words, it represents the site of permanence, stability. a core which is 'natural', and as such is opposed to the constructed, the temporary, the 'un-natural'. It can represent a transcendent notion of self. However what we have here is not Nature, but a representation of it. (And by a figure who does not know which self is 'real', which voice is hers). We are in the world of images, of Baudrillard's 'simulacra.' As Roland Barthes points out, the image completely de-realizes the human world of conflicts and desires, under cover of illustrating it.' (1982, p.55)

Axel, however, holds on to his belief in 'Nature.' The zebra. we are told, won 't vanish. 'It was a survivor.' This, in spite of the fact that the original mural will disappear behind a decorator's paint brush and all Axel is left with is a photograph. An image of an image.

At one level - that of art - the zebra has more-or-less survived: as a product of creativity and imagination. But as a way of figuring the self, it seems highly tenuous and fragile. It is no more than a photograph of a temporary image of an exotic animal produced by a 'mad' young woman. It is quintessentially a postmodern image. It is without history; it is asocial; it lacks all depth; it possesses no interiority.

For twenty-four chapters the novel pushes against the boundaries of realism, especially in the construction of characters. In the episodes involving the zebra, there are magic realist elements. However in the final chapter, the Epilogue, we come firmly down-to-earth. Against the grain of the rest of the narrative, Axel and Rose have been 'rescued' by a scarcely present adult world. Axel is in some sort of group house for those who have contemplated, or attempted, suicide, and Rose is back with her parents.

What are we to make of this?

What the novel seems to be invoking here, very much in the realist tradition, is the emergence of some sort of 'essential'self; one which, against the odds, and inexplicably, has overcome extraordinarily difficult circumstances But the protected and protective world they have entered presumably constitutes the 'hothouse' of the title. In my reading, this must represent the 'unreal' world - and yet it is in this world that the 'Author's note' to the novel suggests that these 'exquisite and rare flowers... reach their most beautiful'. Typically, hothouse flowers get burnt, one way or another, when they're taken out of their environment, and in the last line of the novel it seems that Axel is re-entering the deranged world from which he has temporarily escaped.

Margaret Clark's Back on Track: Diary of a Street Kid is, superficially, in the genre of gritty realism with that smartypants narrative voice that we have come to associate with adolescent narrators, in this instance the 15 year-old Simone whose life story is not a pretty one. She finds her mother dead with a bottle of Jim Beam by her side; she leaves home for a supposed boy friend who is manipulative and violent; she is pack raped twice; she has a miscarriage: she is a drug addict and a thief. In terms of its emphasis on the influence of family histories and environment it might be thought of as closer to the determinism that characterises naturalism, rather than realism.

But in a way, it's a novel that subverts its own naturalistic ground, and begins to reveal its postmodern credentials. Take, for example, this passage describing a Christmas day party put on for the different gangs of street kids, partly organized by Kez, a youth worker.

Taza's gang was there, and a heap of the Homies. 
'Peace on earth and goodwill to all men, 'said Kez, when (irace [a Koori] and this Asian babe started elbowing each other because they'd both gone for the biggest turkey drumstick on the table.

Grace wasn't feeling flash: she had a mountain of a hangover, and I wasn't feeling much better.

'Nothin' 'bout women bein' peaceful, but, 'said Grace, and shoved the gook clear across the room. 'You Homies don't even believe in Christmas, so what ya doin' here then? Just wanna fill ya faces, eh

It was a full-on gang brawl, food flying, flick knives flashing, and even a machete carving up the mince pies. (It just missed my ear as I reached for a pie).

I stood back with Kez against the wall and watched the action. She was too sensible to try and do anything. The other youth workers were trying to break it up, and getting decked for their trouble. I couldn't be bothered fighting. It suddenly seemed kinda childish.

'So, 'I said to Kez, as a bowl of wine trifle splattered onto the wall above my head. 'Did you get my postcard?

'Yeah. Thanks.

Ke- ducked a sausage roll.

'I didn't tell ya, Rory's dead.

'Oh no! What happened?

(Clark 1995. pp.172-3)

The fact that one can't take a passage like this seriously could be seen as signalling some inadequacy in the writing. However, I see it in terms of the impossibility of sustaining traditional realism in the contemporary world. It is a moment when the novel begins to subvert the conventions of realism. There are a number of comments I would like to make about the extract. Firstly, its indebtedness to slapstick comedy is very evident. The humour lies in the visual 'jokes' and the gap between the high seriousness of announcing a death and the surrounding chaos. Here, and elsewhere, there is little of the 'interiority' that we might associate with the realist subject. All is surface in spite of the extraordinary grimness of Simone's life, and that of her friends. Secondly, it is relatively easy to argue that this writing goes well beyond the notion of authentic diary entries, which it is supposed to be. What we have is a well constructed, well paced novel with all sorts of dialogue and description.

The self-reflexive elements of the narrative - typical of modernist and, especially, postmodernist works - are explicitly established in a scene where Simone is asked by a friendly lawyer whether she would consider rewriting her diary for publication. Of course in reading the published book called Back on Track which poses as a diary, we know in a sense that she took up the offer. But on the other hand we also know that this is a novel written by Margaret Clark, not Simone Fawkner. Regardless, the constructed nature of the narrative is foregrounded, and so therefore is the constructedness of the subject position. Simone 'makes herself up' in the act of writing. She is not the unified, given. liberal humanist subject that we might expect from a realist narrative. We are presented with the postmodern, textual self - rather than some unmediated mirroring of the 'real'. And yet the novel continues to gesture towards a consensus notion of identity. At its end Simone is in therapy, in school and looking for her family. She asks her 'shrink', Pam, whether she is back on track. Pam replies,

'It depends on what track you want to be on, Simone. What do you think?'

\section{'Dunno.'}

But I do know, deep down (p. 197)

What does Simone 'know'? Firstly she suggests that she is 'an ungrateful little shit'. Secondly that, 'It's all a veneer, this new Simone Fawkner. One big cover up. ' But finally. in the last words of the novel, But then maybe if I spade deep enough, shovel out enough shit... maybe I'll find something worth keeping...' (p. 198).

We are ultimately back with a notion of a core self, the real, and of course the notion that there is a recognisable 'track.

Finally, a novel which works more consistently within a postmodernist mode, is Isobel Carmody's Greylands. Characteristically, it establishes its postmodern credentials 
by its self-reflexivity: it draws attention to its constructedness in three chapters called 'The Beginning', 'The Middle' and 'The End'. The use of these titles acknowledges, explicitly, a narrative tradition: the (traditional) notion of 'story' with a beginning, a middle and an end. Carmody underlines the claim for the textuality of subjects and events by having two of her characters - Jack and Ellen, sister and brother - debate the issue in the opening lines of the novel in which they question the authority of the text they are part of.

'That is not the beginning', Ellen said, pointing to where Jack had written about the sky.

Jack replies that he is writing in his own way about how it was after their mother died, which means that he is 'making stuff up,' because

\section{You have to. Real life isn 't like a story with abeginning and a middle and an end. It 's everybody's stories all muddled together. But this will be my story.. (Carmody 1997, p.1)}

Ellen has a competing notion of story. She believes Jack should start with 'Once upon a time, in a faraway land, Jack had a dream. ' (p.1). Such an introduction raises, very deliberately. questions not only about narrative tradition. but big issues like 'truth', and how one makes up oneself and one's life through the act of narration. The self is not an autonomous 'given' in this world.

The idea of a story within a story or an embedding and embedded narrative, is not unusual. However Carmody goes beyond the conventions governing such narratives by blurring the boundaries between these worlds. There are arguably four levels operating here. There is an author, Carmody, who creates a narrator, Jack. There is the world in which Jack writes in the three chapters mentioned. There is the world of which Jack writes, firstly the 'real' social world and secondly. Greylands, the other world. However the boundaries between these worlds are not at all secure. Characters leak' from one world to the other in such a way that their status is not clear. But most disconcerting for this reader is that the novel makes no attempt to convince us that Jack, at maybe 12 years of age, could possibly write such complex and sophisticated prose where he creates himself in the third person as a character within the fiction. In fact the novel works, I presume quite consciously, to convince us otherwise. The (so-called) fictional Jack is often confused and uncertain as to what is happening in the world of Greylands. After his first experience of this other world, he raises a troubling question with Ellen:

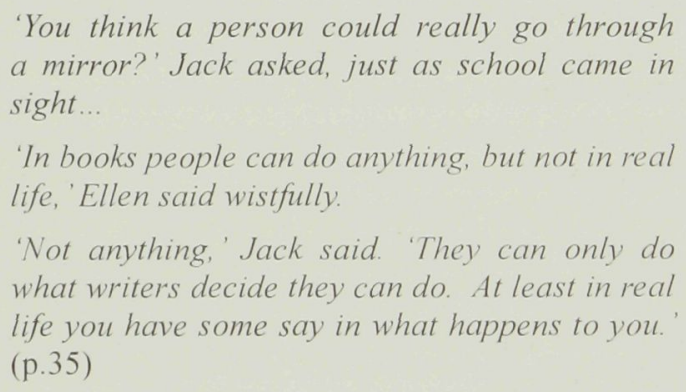

Jack's problem is that his visit to Greylands was not something he seemed to have any control over - either in 'real' life or as the subject of (his own) fiction.

Because the overarching embedding narrative bears such an unconvincing relationship with the other levels, questions are raised, in the words of Brian McHale, about 'narrative authority, reliability and unreliability, the circulation of knowledge and so forth. '(McHale 1987 in Waugh, Patricia, p. 217). And, of course, questions are raised about the stability of identity. Is the 'real' Jack the supposed author, the character in the real world, or the character in Greylands? The glib answer to this question is: all three, but this response ignores the problematic nature of the complex and contradictory relationships between these worlds

The novel gives voice to a contemporary relativism on numerous issues. Alice says about life in Greylands: 'Everything is changing all the time. Everything shifts and things shiver from one form to another. Nothing is certain'. (p.48)

The lack of that liberal humanist core, the autonomous self is voiced by the laughing beast who spells out the role of language in the construction of identity: 'Well, naming is what happens to everything in the end. Names and cages. First I was named, and that shaped me as I am.' (p.79). This statement represents the self as a discursive product, not a pre-ordained given. 
And, a final example, the status of knowledge itself is not only examined through the construction of multiple worlds, but also quite explicitly in the dialogue: 'It's good to want to know things,' said Jack defensively. Alice replies, 'It is? What happens when there is no answer?' she sneered (p.103).

It is my contention that the chapters entitled The Beginning, The Middle and The End do not succeed in constructing a credible narrative position and, as such, they appear as no more than a (self-conscious) gesture towards establishing a traditional subject position - one which is in control and which does possess considerable autonomy. Nevertheless, their very presence does suggest that this novel, although far more consistently representative of a postmodern subjectivity, balks at an unqualified claim for such a position.

In their different ways these three novels suggest a 'crisis' in subjectivity: neither a secure realist position nor a confident adoption of the postmodernist subject. We could speculate that they represent current social and cultural uncertainties about identity within the Australian context; or that they are a product of literary conservatism. Or more challengingly, we might conclude that they embody a claim to a subject position that rejects an either/or model of the subject as autonomous being vs the subject as product; the subject of the realist text vs the subject of the postmodernist text.

The Marxist writer Terry Eagleton gives voice to this position when he notes, firstly, that the contemporary subject could be described as

a dispersed, decentred network of libidinal attachments, emptied of ethical substance and psychical interiority, the ephemeral function of this or that act of consumption, media experience, sexual relationship, trend or fashion. The unified subject 'looms up in this light as more and more... a hangover from an older liberalepoch of capitalism. (Waugh 1992, p.158)

But this is not Eagleton's final position. Somewhat unfashionably, he argues that the bourgeois humanist subject is 'not in fact part of a clapped out history we can all agreeably or reluctantly leave behind.' (p 158). His position is, at base, postmodern when he rejects an either/or model, and opts for a contemporary subject which may enact dual roles:

The subject of late capitalism, in other words, is neither simply the self-regulatory synthetic agent posited by classical humanist ideology, nor merely a decentred network of desire, but a contradictory amalgam of the two.

(p. 158)

In varying degrees, the three novels discussed in this paper endorse Eagleton's claim to the possibility of a subject position which embodies a 'contradictory amalgam' of ideologies - and, by extension of literary conventions. As such, these works could be seen to represent a new realism within Australian children's literature.

\section{REFERENCES}

Althusser, Louis (1977) 'Ideology and the State', in Lenin and Philosophy and Other Essays trans B. Brewster. London, New Left Books, in Rice, Philip \& Waugh, Patricia (1989) Modern Literary Theory: A Reader. London, Edward Arnold.

Barthes, Roland (1982) Camera Lucida. Reflections of Photography. trans. Richard Howard, London, Cape, cited in Wheale, Nigel (1995) The Postmodern Arts. London, Routledge.

Belsey, Catherine (1980) Critical Practice. London, Methuen.

Carmody, Isobel (1997) Greylands. Ringwood Victoria, Penguin.

Clark, Margaret (1995) Back on Track: Diary of a Street Kid. Sydney, Random House.

Eagleton, Terry. (1985) From 'Capitalism, modernism and postmodernism' New Left Review 152,1985 , pp.60-73 in Waugh, Patricia (1992), Postmodernism: A Reader. London, Edward Arnold.

Hilton, Nette (1997) Hothouse Flowers. Sydney, Angus \& Robertson.

McHale, Brian (1987) Postmodernist Fiction. London, Methuen, in Waugh, Patricia (ed) 
(1992) Postmodernism: A Reader. London, Edward Arnold.

Rice, Phillip and Waugh, Patricia (1996) Modern Literary Theory: A Reader ( $3^{\text {rd }}$ edn). London, Arnold

Stephens, John (1996) 'Children's literature, interdisciplinary and cultural studies' in Bradford, Clare (1996) Writing The Australian Child. Nedlands, UWA Press, pp.161-180.

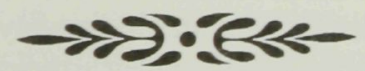

\section{ACKNOWLEDGEMENT}

We thank Richard Rossiter for permission to reprint this article which first appeared in Pope, Robin (ed) (2001) Children's Literature Matters (ACLAR, Melbourne, 2001).

\section{$\rightarrow 20 \%$}

\section{BIOGRAPHICAL NOTE}

Richard Rossiter is a senior lecturer at Edith Cowan University, where he teaches Australian literature and literary theory. He is extensively involved in supervising postgraduate writing students, including recent Vogel award winner, Danielle Wood ('The Alphabet of Light and Dark') and Young Adult fiction writer, Julia Lawrinson. He has publications examining Australian fiction (especially Tim Winton and WA writers more generally), and in children's literature. 